Article

\title{
Formulating Assessment Indices and Strategies for the Transition to Local Industrial Development in Taoyuan City, Taiwan
}

\author{
Yung-Cheng Pan ${ }^{1}$ and Yin-Hao Chiu ${ }^{2, *}$ \\ 1 Department of Architecture and Urban Design, Chinese Culture University, Taipei 11114, Taiwan; \\ sduarch@gmail.com \\ 2 Department of Urban Development, University of Taipei, Taipei 11153, Taiwan \\ * Correspondence: yhchiu@go.utaipei.edu.tw; Tel.: +886-2-2871-8288 (ext. 3102) \\ Academic Editor: Tan Yigitcanlar
}

Received: 26 October 2016; Accepted: 27 February 2017; Published: 2 March 2017

\begin{abstract}
Local industries are crucial for enhancing urban competitiveness and are closely related to national economic performance. To sustainably develop local industries, a set of assessment indices should be formulated in addition to factors such as geographical environments, cultural history, development processes, and industrial structures for governments to promote development policies while satisfying the goal of sustainable industrial development. This study first adopted the fuzzy Delphi method to construct the indices for assessing local industrial development, referred to the action plans for the six key industries formulated by the Executive Yuan of Taiwan, and subsequently integrated the analytic hierarchy process and analytic network process to determine the order of priority for policies facilitating local industrial development for future reference. The results indicated that infrastructure, innovative research and development, and government policies are crucial bases for local industrial development. Furthermore, this study adopted Taoyuan to verify these indices and compiled expert suggestions to indicate that the government should prioritize the development of the biotechnology, green energy, and medical care industries. When developing local industries in the future, a set of assessment standards and policy analyses should be established for the government to enhance local industrial development and thus increase international competitive advantages by fully ascertaining the factors for industrial success and the characteristics of local advantages.
\end{abstract}

Keywords: local industry; fuzzy delphi method; analytic network process

\section{Introduction}

The formation and development of local industries depend upon local social background, natural resource conditions, production, supply and demand, and overall commercial activities. However, globalization, changes in industrial structure, and information technology development have forced local industries to restructure, upgrade, or transform themselves to improve their competitiveness in response to competition. The rise of local industries can boost local economic development and serve as an essential foundation for improving local residents' employment rate and standard of living. Moreover, local economic development is the main source of a city's competitiveness. Liau and Chou (2000) [1], Fan and Chou (2008) [2], and Barberia and Biderman (2010) [3] studies on local industries have discussed the effects of industrial development strategies on local places, or focused on industries with distinctive local features to examine their development contexts, influences, and strategies. The present study explored factors affecting local industrial development. Key success factors are frequently employed to discuss industry characteristics; the factors presume that organizations must grasp several crucial factors in order to seize advantages, support long-term business development, 
and succeed in management (Leidecker and Bruno, 1984) [4]. The sustainable development of local industries requires the understanding and consideration of conditions such as geographical environments, developmental processes, and industrial structures, as well as available resources.

A review shows that previous strategies for local economic development in Taiwan have mostly been directed by governmentally enforced policies; the Taiwanese government has designed a series of national economic development strategies and effectively intervened in the development of industrial clusters through state-owned businesses to facilitate industrialization and social development (Ching and Chou, 2007 [5]). The government has also introduced numerous policies related to local development. For example, the Ministry of Economic Affairs promoted the project of One Town One Product to assist industries with distinctive local features in order to achieve the overall objectives of industrial economy, namely improving local development, urban-rural balance, local employment, and national income. The government planned to establish the Local Industry Exchange Center as a platform for research and development (R\&D), innovation, learning, human resource, and exchanges of human resources and information to invigorate local industries (White Paper on SMEs, 2005 [6]). In Challenge 2008: National Development Plan, the Executive Yuan formulated the Rural Industrial Development Project for Assisting Local Industries and Cultures to facilitate agricultural upgrade and invigorate rural communities (Council for Economic Planning and Development, 2005 [7]). Similarly, the Ministry of Culture, Council of Indigenous Peoples, and Hakka Affairs Council have individually proposed industrial plans and policies that stress local features. Both the central and local governments have actively sought industries with distinctive local features for local places, provided counseling and innovation suggestions, implemented interdisciplinary integration and development, and facilitated local industrial upgrade and transformation to increase local employment and economic development. In the era of globalization and internationalization, the rise of China and Southeast Asian countries have confronted industries in Taiwan with transformation and changes in industrial structures. However, how local industries in Taiwan should cope with the transformation and challenge to maintain a satisfactory quality of life, improve their economic levels, and enhance competitiveness remains a question. Accordingly, this study establishes a set of local industrial development assessment indices and strategies for the government to accurately and effectively promote and guide local industries according to their developmental features and expectations.

This study conducted empirical research in Taoyuan City due to the similarity of the transformation and changes of industrial structure in Taiwan. Taoyuan City used to focus on developing heavy industry and have 29 industrial zones which the industrial output ranked the highest in Taiwan. However, the government is also seeking the opportunity for the high-tech manufacturing industry. After Taoyuan City was upgraded to a municipality in 2014, the population reached 2.14 million, ranking fifth among the six municipalities at the end of 2016 (Taoyuan City Government, 2015 [8]). In 2008, the Kuomintang (KMT) government has proposed Taoyuan Aerotropolis as the crucial national development plan, thus, an increasing amount of resources has been channeled into the city. Both the central and local governments have actively sought to build Taoyuan City into an aviation city that serves as a national gateway of Taiwan, and therefore the city is facing a challenge of transformation. There are four crucial objectives in the Taoyuan Aerotropolis project: Firstly, providing a well-linked system of industries, transportation and the inner city to boost the development. Secondly, creating the modern city lifestyle toward a sustainable and intelligent future. Thirdly, leading the up-coming industrial transformation of high-tech industries. Lastly, driving the high-tech industrial development of Taiwan and boost the international competitiveness (Taoyuan City, 2015 [8]). Moreover, after the party alternation in 2016, the new government also proposed the new industrial plan named Asian Silicon Valley and aimed to build the city as the hub of the Internet of Things (IoT), R\&D and the innovation central in Taiwan. In addition to its own development, Taoyuan City would become engaged in new interactions with neighboring cities after being upgraded to a municipality. This situation necessitated reassessing the suitable types of industries for Taoyuan City to develop at this particular timing; therefore Taoyuan City is targeted in the present empirical study. 


\section{Literature Review}

\subsection{Local Industrial Development}

This section summarizes and introduces local industrial clusters, industries with distinctive local features, and local industrial development in Taiwan. The objective of this section is to clarify the types and characteristics of local industrial development, ascertain factors affecting such development, and determine key factors that affect the development of local industries. Multiple studies have indicated that an industrial cluster is a type of agglomeration economy (Porter, 1998 [9]; Cooke et al., 1998 [10]; Cooke, 2001 [11]; Ching and Chou, 2007 [5]; Lin et al., 2012 [12]). In the cluster, homogenous industries and competing or cooperating businesses are associated with one another in inter-industrial economic activities because of geographical factors, gaining profits through the demands of different industries. Moreover, an industrial cluster can be developed by building a close production network for mutual support, interaction, and learning to improve its technology and global competitiveness. Industrial clustering effects have become crucial to global industrial development. Industrial clusters can maintain the sustainable development of regional industries while improving regional and local competitiveness. In particular, local competitiveness is founded on industrial clustering networks and the system of innovation and learning.

Lin et al. (2012) [12] explore the time point when industries in Taiwan started to cluster, examined the clustering process, and determined the subsequent effects of industrial clusters on businesses and local places. Yen and Kung (2014) [13] observe the mode of industrial clustering in Taiwan and find that domestic manufacturers have mostly clustered horizontally or concentrated during development. Particularly, large-scale businesses tend to concentrate and develop horizontally. In addition, the domestic industrial model involves division of labor at different levels in urban and rural areas according to market demands. In addition to horizontal clustering, industries cluster vertically or spatially, using industries or departments that have competitive advantages as a driving force to facilitate overall industrial development (Yung et al., 2009 [14]).

Industrial clustering in Taiwan is conspicuous and has been fairly developed. Ching and Chou (2007) [5] analyze clusters in Northern, Central, and Southern Taiwan; determine the impact on different industrial clustering areas in recent years and the differences between them; and examine the part of the government in local industrial development and the effects of technological communities on industrial clusters. According to the study, when industrial clusters in Taiwan faced intense competition, part of the industries were not defeated nor eliminated from the market. Instead, competition facilitated industrial clusters to grow; develop close production networks to support, interact with, and learn from one another; improve technology and global competitiveness; and become integrated in the global production network. Accordingly, technological concentration, innovation, and establishment of learning networks derived from clustering are crucial factors for the continual development of local industries. Yu et al. (2010) [15] investigated the lotus industry in Baihe District, finding that industries with distinctive local features are characterized by regional centralization, geopolitical relationships, and small industrial scales, and can be easily supported and developed through the means of industry design. Chen (2007) [16] discussed the current development of domestic industries with distinctive local features and the trend of local industrial development. Chen summarizes the objectives of future local industrial development, including expanding the international market, improving product innovation and refinement, developing talents for supporting industries with distinctive local features, and strengthening the consensus between the government and private businesses. Liau and Chou (2000) [17], Fan and Chou (2008) [2], and Barberia and Biderman (2010) [3] have indicated that local industrial development and regeneration should be explored using external structural factors and realized through the improvement of internal autonomy. External factors include the development and direction of overall national policies, improvement of regional economies, and flexibility in national land control. External factors include the creation of regional job opportunities, association between 
cultural activities and regional consumption, and improvement of professional services. These factors are essential to local development.

Liau and Chou (2000) [17] revealed that key factors for local industrial development in Taiwan include the improvement of local competitors, flexibility in national land control, mobility of information technology, provision of job opportunities and technical training, association between culture and consumption, and enhancement of professional services. Accordingly, policy coordination and technological innovation are the most critical factors for local industrial development. Liau (2005) [18] also indicated that the conditions and opportunities of local development for local counties and cities in Taiwan are still affected by state regulation and strategies. These external structural factors, the elevation of internal autonomy, and the construction of institutional environments are crucial elements that counties and cities in Taiwan must emphasize for local development. Although local industrial development is strongly influenced by government policies and strategies, Fan and Chou (2008) [2] argued that national intervention does not guarantee success, particularly in weakly structured and underdeveloped areas. Failing to delve into the intricate network structures of local places may increase the possibility of governance failure. In addition to specific industries directed by the government, most local industries are formed through the integration of local development and natural resources. Industries and the government should focus more on integrating and developing resources, as well as establishing industries with distinctive local features, to boost the competitiveness of these industries. Therefore, despite the guidance of government policies, the success of local industries still depends on whether or not they are supported by effective and strong local networks.

\subsection{Local Industrial Development Indicators}

Policies for local industries undergo constant changes and adjustment depending on economic and social development. Either directed by the market or the government, local industries must be developed through the coordination of fiscal, monetary, and national development policies. Moreover, industrial policies are the most effective when they are within the fields that the government is interested in and capable of coping with. Therefore, to formulate policies effectively, the government should comprehensively analyze, verify, and assess policy proposals while providing feedback and correction. Given these efforts, each industry still requires individual strategies and promotion plans. Table 1 compiles the major industries and development strategies of several countries.

Table 1. Major industries for development in several countries.

\begin{tabular}{|c|c|c|c|c|c|c|c|}
\hline Industry & United States & Britain & Singapore & China & Korea & Hong Kong & Taiwan \\
\hline Environmental protection & (-) & (-) & (-) & (-) & () & () & () \\
\hline Biomedicine & () & (-) & - & (?) & () & (-) & () \\
\hline Cultural and creative industry & (?) & ()) & - & () & (?) & (-) & (-) \\
\hline $\begin{array}{l}\text { High value-added } \\
\text { manufacturing }\end{array}$ & () & () & () & () & () & - & - \\
\hline
\end{tabular}

In response to global trends such as energy conservation and carbon reduction, population aging, and the rise of creative economy, the KMT government proposed six key emerging industries in April 2009, combining the already competitive information and communication technology industries (including communications, information, optoelectronics, and semiconductor) with biotechnology, green energy, quality agriculture, tourism, medical care, and cultural and creative industries. The Executive Yuan proposed specific strategies in terms of product diversification, branding, and acquisition of key technology, investing government resources with careful plans, providing counseling, and attracting private investments to expand industrial scale, increase output value, 
and facilitate business opportunities related to emerging industries. These measures assisted with the industrial transformation and upgrade of Taiwan, supporting continual economic growth while maintaining people's quality of living. This study refers to the six key emerging industries of 2009 for policy formation (National Development Council, 2009) [19]. After the party alternation in 2016, the Democratic Progressive Party (DPP) government proposed a new direction for industrial development, namely, the five plus two industries that incorporate digital economy. These industries include five major innovative industries (i.e., biomedicine, establishment of an Asian Silicon Valley, intelligent machinery, green energy technology, and national defense and aerospace) plus developing a new agricultural scheme and a circular economy (National Development Council, 2016) [20]. Table 2 compares the two industrial plans proposed in 2009 and 2016. In contrast to the industrial goals set in 2009, the goals in 2016 incorporate machinery, national defense, and aerospace without placing equal emphasis on cultural and creative industry and tourism. The culture and creative industry tends to cooperate with varies industries such as biotechnology, green energy, medicine and the agriculture industries. On the other hand, the decline of tourists from China also influences the tourism industry since the DPP party came into power. In short, the new industrial policies tend to stress technological innovation and industry. The present study primarily focused on local industrial development in Taiwan, and was subjected to research time limitations. Therefore, the action plan of six key emerging industries proposed by the Executive Yuan in 2009 is used as the project for strategy development in this study, whereas the new policy proposed in 2016 is used as a supplementary reference.

Table 2. Directions of Taiwan's industrial development policies.

\begin{tabular}{ccc}
\hline & Six Key Emerging Industries in 2009 & Five Plus Two Industries in 2016 \\
\hline Medicine & $\odot$ & $\odot$ \\
Biotechnology & $\odot$ & $\odot$ \\
Green energy & $\odot$ & $\odot$ \\
Agriculture & $\odot$ & $\odot$ \\
Tourism & $\odot$ & - \\
Cultural and creative industry & $\odot$ & - \\
Machinery & - & $\odot$ \\
National defense & - & $\odot$ \\
Aerospace & - & $\odot$ \\
\hline
\end{tabular}

\section{Establishing Local Industrial Development Indicators}

\subsection{Local Industrial Development Indicators}

Buckley et al. (1988) [21] specify four levels of competitiveness (i.e., national, industry, firm, and product levels) and indicate the high correlation among them. Industry and firm competitiveness must be improved prior to enhancing national competitiveness, and firm competitiveness must be increased before industry competitiveness can be strengthened. In other words, industries are interconnected. Among international competitiveness ratings, currently the Lausanne-based International Institute for Management Development in Switzerland, Geneva-based World Economic Forum, China-based Global Urban Competitiveness Project, and UK regional competitiveness index have established indicators of national competitiveness to rank the competitiveness of countries worldwide. The four sub-indices in The World Competitiveness Yearbook released by the International Institute for Management Development are economic performance, government efficiency, business efficiency, and infrastructure. The three global competitiveness sub-indices in the Global Competitiveness Report released by the World Economic Forum are basic requirements, efficiency enhancer, and innovation and sophistication factors. China's Global Urban Competitiveness Project employs three dimensions to compare and analyze cities worldwide. The project develops the comprehensive competitiveness index from the perspective of output, compiles the environmental index of production factors through input, and constructs the industry competitiveness index through 
industrial structure to rank cities. The UK regional competitiveness index is adopted to assess industry competitiveness in European regions. The index includes aspects such as R\&D capacity, economic growth, and industrial performance that are considered through internal and external factors. Among domestic studies on competitiveness, Lee and Yen (2006) [22] divided the development and competitiveness of industries with distinctive local features into five dimensions, namely, government, natural environment, humanities and society, operator, and product. The five dimensions influence the levels of localization, industrialization, and characterization in local features, thus affecting the competitiveness of industries with distinctive local features. Huang (1998) [23] argued that industrial planning must consider factors external and internal to the industry. In other words, the macro aspects (e.g., external environments, industrial structures, public facilities, and social responsibility) and micro aspects (e.g., production, distribution, revenue, and benefits) of the industry must be considered during industrial planning. Coelli et al. (1998) [24] claimed that the determinants for local economic development are divided into internal basic conditions and external factors. Internal basic conditions include land price, industrial structure, public facilities and the services provided by them, environmental laws and regulations, and local capital markets. External factors include global economy, macroeconomic policies, financial and fiscal policies, and energy and transportation policies. Yao et al. (2001) [25] indicated that industrial productivity may be affected by multiple factors. For example, the level of infrastructure and public services, degree of clustering of regional activities, and regional accessibility are conditions that multiple scholars have valued. Local conditions are important, including the distribution of natural and creative resources; local labor and productivity; positive and negative incentives for investment; provision of infrastructure; centralization of $R \& D$, production, and marketing; economic systems and government policies; and institutional framework of resource allocation (Dunning, 1993) [26]. Yu et al. (2010) [15] established the spatial structure of industries with distinctive local features according to industrial economics and Porter's Diamond model from the perspective of the overall operational structure of local industries. They mainly adopt two viewpoints, namely the pull factor within the industry and the push factor from the government, to individually examine the three dimensions of industry fundamentals (i.e., factors of production and demand), industrial organization (i.e., business strategies, business structures, horizontal competition, and related and support industries), and industrial policy, as well as their relationships. Although factors affecting industries with distinctive features are complex and intricate, they can be summarized through spatial analysis as whether or not an industry has the market advantages to attract consumers from other areas and expand its scope of sales. Therefore, the supply factors embedded in a firm's cost and the consumer-based demand factors can be examined to understand the development potentials and limitations of an industry with distinctive features (Taiwan Institute of Economic Research, 2001 [27]). Dimensions of domestic and international industrial competitiveness indices are compiled in Table 3. 
Table 3. Dimensions of domestic and international industrial competitiveness indices.

\begin{tabular}{|c|c|c|c|c|c|c|c|c|c|c|c|}
\hline $\begin{array}{l}\text { Index Dimension Institute } \\
\text { and Research }\end{array}$ & $\begin{array}{l}\text { Economic } \\
\text { Performance }\end{array}$ & $\begin{array}{l}\text { Government } \\
\text { Policies }\end{array}$ & $\begin{array}{c}\text { Business } \\
\text { Efficiency }\end{array}$ & Infrastructure & $\begin{array}{c}\text { Innovative } \\
\text { R\&D }\end{array}$ & $\begin{array}{c}\text { Industrial } \\
\text { Performance }\end{array}$ & $\begin{array}{l}\text { Humanities } \\
\text { and Society }\end{array}$ & $\begin{array}{l}\text { Technology and } \\
\text { Techniques }\end{array}$ & $\begin{array}{l}\text { Geographical } \\
\text { Location }\end{array}$ & $\begin{array}{c}\text { Natural } \\
\text { Environment }\end{array}$ & $\begin{array}{c}\text { Social } \\
\text { Responsibility }\end{array}$ \\
\hline $\begin{array}{l}\text { International Institute of } \\
\text { Management Development }\end{array}$ & ๑) & ○ & () & ๑ & & & & & & & \\
\hline World Economic Forum & () & (ㅇ) & (๑) & (๑) & (๑) & & & & & & \\
\hline $\begin{array}{c}\text { Global Urban } \\
\text { Competitiveness Project }\end{array}$ & ๑) & & (๑) & ๑ & & ๑ & ๑ & ๑ & & & \\
\hline $\begin{array}{l}\text { UK Regional } \\
\text { Competitiveness Index }\end{array}$ & ○ & & ○ & & (๑) & ๑ & & ๑ & & & \\
\hline Lee and Yen (2006) [22] & & ๑ & & & & ๑ & ๑) & & & () & \\
\hline Huang (1998) [23] & ๑) & & (๑) & (๑) & & () & & & & & (๑) \\
\hline Coelli et al. (2009) [28] & ๑) & ๑) & & ๑ & & ๑) & & & & ๑) & \\
\hline Yao et al. (2001) [25] & & & & ๑ & & & & & ๑) & & \\
\hline Dunning (2001) [26] & & & & & (๑) & & & & & (๑) & \\
\hline Yu et al. (2010) [15] & ๑) & ๑) & ๑) & & & ๑) & & & & & \\
\hline
\end{tabular}




\subsection{Formulating Criteria and Indices for Assessing Local Industrial Development}

To determine factors for local industrial development, this study referred to literature associated with local industrial development as well as domestic and international industrial competitiveness indices, compiled conditions for local industrial development, and categorized the factors into three major dimensions and 12 criteria: (A) external factors, (B) fundamentals, and (C) network factors. The (A) external factors indicate the impacts from the external political, social and economic environments. As for (B) fundamentals, it refers to the inner labor condition and the industrial R\&D ability. The network factors $(C)$ here show the relationship and connection of each industry. These dimensions are assessed using 12 criteria: (A1) infrastructure, (A2) government policies, (A3) economic performance, (A4) local resources, (B1) labor market, (B2) industrial effectiveness, (B3) technical training, (B4) innovative R\&D, (C1) local identity, (C2) regional networks, (C3) location advantages, and (C4) marketing management. The criteria for local industrial development are individually described as follows and compiled in Table 4.

(1) (A1) Infrastructure: The integrity of the infrastructure in an area that supports the local industry's global communication and circulation of information and people.

(2) (A2) Government policies: The integrity of the support from national policies for an industry that facilitates local industries to expand or transform.

(3) (A3) Economic performance: The macroeconomic performance of a country or region that affects the industrial development of the region.

(4) (A4) Local resources: Whether or not an industry's environment has special industrial and cultural resources, and whether or not the industry has taken advantages of these resources to reduce costs and produce economic benefits.

(5) (B1) Labor market: Labor production capacity of the region where an industry is situated.

(6) (B2) Industrial effectiveness: Contribution of an industry and if it increases added value.

(7) (B3) Technical training: The cultivation and incubation of professional and versatile talents for the industries of an area.

(8) (B4) Innovative R\&D: Whether or not the internal operation of an industry has the capability to innovate and the mechanism to adjust production; industrial profits are incorporated as a factor for assessing industrial innovation.

(9) (C1) Local identity: The positive and negative evaluations and the level of support from local residents for an industry.

(10) (C2) Regional networks: Whether or not an industry is closely connected with local communities, and whether or not the industry's development organizations have guided and financially supported the communities to gradually expand its businesses.

(11) (C3) Location advantages: Whether or not the location and development direction of a local industry meets the demand of nearby cities, and the prospect of employment and economic growth of regional industries.

(12) (C4) Marketing management: The establishment of local industry brands to facilitate industry promotion and marketing.

\subsection{Questionnaire Results Based on the Fuzzy Delphi Method}

Factors for assessing local industrial development were adopted to develop an expert questionnaire based on the fuzzy Delphi method (FDM). This study invited five experts from the industries, government, or academia to be questionnaire respondents. These experts engaged in research or teaching related to local industries, and had sufficient professional knowledge and understanding of local industrial development. All the distributed expert questionnaires were retrieved and valid. After referring to the FDM calculations adopted by Jeng (2001) [29], this study used double triangular fuzzy numbers and conducted a gray zone test to determine the convergence of the 
assessment factors in order to understand if expert opinions on the factors tended to be consistent. The assessment and selection results derived from the FDM calculations are presented in Table 5. All the values obtained through the questionnaire are within the range of $\mathrm{SD} \times 2$, and the test value $\mathrm{Zi}$ for every index is larger than zero, indicating the convergence of the assessment indices and a high consistency among the expert opinions.

Table 4. Criteria and factors for assessing local industrial development.

\begin{tabular}{|c|c|c|c|}
\hline Objective & $\begin{array}{c}\text { Targets of } \\
\text { Assessment }\end{array}$ & Criteria & Assessment Factors \\
\hline \multirow{9}{*}{$\begin{array}{l}\text { Criteria for } \\
\text { assessing } \\
\text { local } \\
\text { industrial } \\
\text { development }\end{array}$} & \multirow{2}{*}{$\begin{array}{l}\text { External } \\
\text { factors }\end{array}$} & A1 Infrastructure & $\begin{array}{l}\text { A1-1 Convenience afforded by infrastructure and } \\
\text { transportation networks } \\
\text { A1-2 Density and integrity of industrial platforms } \\
\text { A1-3 Soundness of international network communication equipment } \\
\text { and platforms } \\
\text { A1-4 Quality of supply (e.g., energy) }\end{array}$ \\
\hline & & A4 Local resources & $\begin{array}{l}\text { A4-1 Regional natural and tourist resources } \\
\text { A4-2 Locally characteristic customs, cultures, and arts } \\
\text { A4-3 Locally characteristic historic sites and buildings } \\
\text { A4-4 Maintenance of urban landscapes and environmental quality } \\
\text { A4-5 Cost of regional resource utilization }\end{array}$ \\
\hline & \multirow{3}{*}{ Fundamentals } & B1 Labor market & $\begin{array}{l}\text { B1-1 Proportion of labor productivity } \\
\text { B1-2 Flexibility in wages and salaries } \\
\text { B1-3 Ability to attract and retain talents }\end{array}$ \\
\hline & & $\begin{array}{l}\text { B2 Industrial } \\
\text { effectiveness }\end{array}$ & $\begin{array}{l}\text { B2-1 Ratio of industrial production to market demand } \\
\text { B2-2 Soundness of industrial clusters } \\
\text { B2-3 Integrity of industrial value chains and work specialization } \\
\text { B2-4 Scale and number of industries } \\
\text { B2-5 Network among industries } \\
\text { B2-6 Industrial development potential }\end{array}$ \\
\hline & & B4 Innovative R\&D & $\begin{array}{l}\text { B4-1 Service innovation, process innovation, and industrial innovation } \\
\text { B4-2 Investment in industrial R\&D } \\
\text { B4-3 Number of patents } \\
\text { B4-4 Intellectual property and transfer }\end{array}$ \\
\hline & \multirow{4}{*}{$\begin{array}{l}\text { Network } \\
\text { factors }\end{array}$} & C1 Local identity & $\begin{array}{l}\text { C1-1 Identification with local industries } \\
\text { C1-2 Participation and investment in local industries } \\
\text { C1-3 Emerging industries' degrees of tolerance and acceptance }\end{array}$ \\
\hline & & $\begin{array}{c}\text { C2 Regional } \\
\text { networks }\end{array}$ & $\begin{array}{l}\text { C2-1 Public and private partnerships } \\
\text { C2-2 Regional development cooperation platforms } \\
\text { C2-3 Regional cultural elements } \\
\text { C2-4 Assistance from related local associations } \\
\text { C2-5 Links between professional communities and local places }\end{array}$ \\
\hline & & $\begin{array}{l}\text { C3 Location } \\
\text { advantages }\end{array}$ & $\begin{array}{l}\text { C3-1 Facilitating the development of neighboring industries } \\
\text { C3-2 Location quotient } \\
\text { C3-3 Shift share } \\
\text { C3-4 Demand of nearby cities }\end{array}$ \\
\hline & & $\begin{array}{l}\text { C4 Marketing } \\
\text { management }\end{array}$ & $\begin{array}{l}\text { C4-1 Establishment of local industrial brands } \\
\text { C4-2 Cross-industry alliance } \\
\text { C4-3 Local image marketing }\end{array}$ \\
\hline
\end{tabular}


Table 5. Criteria and factors for assessing local industrial development.

\begin{tabular}{|c|c|c|c|c|c|c|c|c|c|c|c|c|}
\hline \multirow{2}{*}{ Assessment Indices } & \multicolumn{2}{|c|}{ Minimum Ci } & \multicolumn{2}{|c|}{ Maximum Oi } & \multicolumn{2}{|c|}{ Singular Value a } & \multicolumn{3}{|c|}{ Geometric Mean } & \multirow{2}{*}{$\begin{array}{c}\text { Test } \\
\text { Value Zi }\end{array}$} & \multirow{2}{*}{$\begin{array}{c}\text { Expert } \\
\text { Consensus Gi }\end{array}$} & \multirow{2}{*}{ Selection $>6.35$} \\
\hline & $\min$ & $\max$ & $\min$ & $\max$ & $\min$ & $\max$ & $\mathrm{Ci}$ & Oi & Singular Value & & & \\
\hline A1 Infrastructure * & 4 & 6 & 8 & 10 & 5 & 6 & 5.14 & 8.56 & 6.72 & 5.42 & 6.85 & Yes \\
\hline A2 Government policies * & 5 & 7 & 8 & 10 & 6 & 9 & 6.15 & 9.36 & 7.53 & 4.21 & 7.76 & Yes \\
\hline A3 Economic performance & 3 & 5 & 5 & 8 & 4 & 7 & 4.13 & 7.09 & 5.88 & 2.96 & 5.61 & No \\
\hline A4 Local resources & 3 & 5 & 6 & 7 & 5 & 6 & 3.73 & 6.58 & 5.38 & 3.85 & 5.15 & No \\
\hline B1 Labor market & 3 & 6 & 5 & 8 & 4 & 7 & 4.68 & 7.28 & 5.67 & 1.6 & 5.63 & No \\
\hline B2 Industrial effectiveness * & 6 & 8 & 8 & 10 & 7 & 9 & 6.55 & 9.17 & 7.76 & 2.61 & 7.86 & Yes \\
\hline B3 Technical training * & 4 & 6 & 6 & 9 & 5 & 7 & 4.96 & 7.92 & 6.35 & 2.96 & 6.44 & Yes \\
\hline B4 Innovative R\&D* & 4 & 8 & 7 & 10 & 6 & 9 & 5.62 & 8.52 & 6.89 & 1.9 & 7.39 & Yes \\
\hline C1 Local identity & 3 & 6 & 5 & 10 & 4 & 8 & 3.96 & 7 & 5.62 & 2.04 & 5.49 & No \\
\hline C2 Regional networks* & 4 & 6 & 7 & 9 & 6 & 7 & 4.74 & 7.95 & 6.38 & 4.21 & 6.35 & Yes \\
\hline C3 Location advantages & 3 & 6 & 6 & 8 & 5 & 7 & 4.28 & 7.35 & 5.97 & 3.07 & 5.82 & No \\
\hline C4 Marketing management & 2 & 6 & 4 & 8 & 3 & 7 & 3.44 & 6.58 & 5.12 & 1.14 & 5 & No \\
\hline \multicolumn{10}{|c|}{ Total number of selected factors: 12} & \multicolumn{2}{|c|}{ Threshold } & 6.35 \\
\hline
\end{tabular}

Note: * Assessment factors that passed the threshold and were selected. 
In determining the threshold for expert consensus, Wu and Huang (2011) [30] indicated that if the values of the questionnaire range from 0 to 10, the threshold is usually set at 5.0-7.0. Therefore, the geometric mean of consensus values is generally adopted as the threshold, and indices with a consensus higher than the threshold are considered to meet the standard of expert judgment. After FDM calculations, a line chart was used to perform a screen test, and the threshold for expert consensus was set at 6.35 (i.e., threshold value $\geq 6.35$ ) according to the sudden decline of the slope in the line chart. According to Table 6, the six factors having an expert consensus higher than the threshold of 6.35 are presented in a descending order as follows: B2 (7.86), A2 (7.76), B4 (7.39), A1 (6.85), B3 (6.44), and C2 (6.35). The experts have reached consensus over the six assessment factors, considering them to be more crucial for local industrial development. Therefore, this study included the six factors as key criteria affecting local industrial development, and used them as a basis of assessment and comparison in the subsequent analytic network process (ANP).

Table 6. Indices of local industries: assessment factors and expert consensus Gi.

\begin{tabular}{cccccc}
\hline \multicolumn{2}{c}{ Crucial Assessment Indices Passing the Threshold of 6.35 } & \multicolumn{2}{c}{ Assessment Indices Failing to Pass the Threshold of 6.35 } \\
\hline Rankings & Assessment Factors & Expert Consensus Gi & Rankings & Assessment Factors & Expert Consensus Gi \\
\hline 1 & B2 Industrial effectiveness & 7.86 & 7 & C3 Location advantages & 5.82 \\
2 & A2 Government policies & 7.76 & 8 & B1 Labor market & 5.63 \\
3 & B4 Innovative R\&D & 7.39 & 9 & A3 Economic performance & C1 Local identity \\
4 & A1 Infrastructure & 6.85 & 10 & A4 Local resources \\
5 & B3 Technical training & 6.44 & 11 & C4 Marketing \\
6 & C2 Regional networks & 6.35 & & management \\
\hline
\end{tabular}

\section{Strategic Plans for Local Industries}

\subsection{Framework of the Strategic Plans for Local Industries}

Before implementing an ANP questionnaire involving paired comparison, an expert panel was held on the mutual influences between the six assessment factors in order to determine if factors obtained using an FDM threshold were internally interdependent. Subsequently, the ANP was performed to compare the priority of each development strategy as a major basis for the empirical research on local industrial development strategies. The internal interdependence among the six assessment factors is detailed in Figure 1. The framework of local industrial development assessment indices and strategies is illustrated in Figure 2.

Following Table 1, which shows the major industries in different countries, this study primarily focused on local industrial development in Taiwan. Therefore, the action plan devised by the Executive Yuan for the six key emerging industries in 2009 was used as a strategic development plan in this study. The six industries are as follows:

(1). P1: Biotechnology industry

Biotechnology incorporates the fields of health (e.g., medicine, pharmaceutical biotechnology, and medical technology), industry (e.g., chemistry, energy, materials, and foods), and agriculture (e.g., agriculture, husbandry, fishing, and forestry). The biotechnology industry should improve its capacity for industrialized $R \& D$, continue the accumulated outcomes from upstream businesses, develop biotechnology integration/incubation centers and venture capital funds, encourage private investments, and establish a food and drug administration to construct a medical regulatory environment compatible with the international community.

(2). P2: Green energy industry

The green energy industry mainly focuses on renewable energy (e.g., solar photovoltaic and wind power) and energy conservation (e.g., LED photoelectric lighting and energy information and communication). This industry should adopt strategies such as technology advancement, 
critical investments, environmental shaping, domestic demand expansion, and export promotion to strengthen the competitive advantages of solar cell technology, guide businesses to create an offshore wind power market, and improve the advantages in the production and system of LED lighting components. By doing so, the industry will enhance its industrial capacity through the domestic market, concentrate on advanced metering infrastructure systems and energy management programs, and create an overseas niche market.

\section{(3). P3: Quality agriculture}

Grounded on the concepts of health, excellence, and Lifestyles of Health and Sustainability (LOHAS), quality agriculture actively develops excellent products, opens up new markets, and facilitates rural regeneration. The concept of health aims to build an agricultural island free from toxins; the idea of excellence is directed on developing new agricultural technologies for Taiwan and initiating a value-added use of intellectual property; and the concept of LOHAS seeks to develop in-depth agricultural tourism and an agricultural luxury industry.

\section{(4). P4: Tourism}

On the basis of high-quality, distinctive, smart, and sustainable tourism, this plan features counseling and the optimization of industries, systems, and talents. By integrating interdisciplinary characteristics, establishing tourism platforms, and developing in-depth, diverse, and high value-added distinctive tourism products, this plan seeks to integrate with information and communications technology to provide ubiquitous tourism services while promoting green and caring tourism to open up new tourism business opportunities and facilitate sustainable tourism development.

\section{(5). P5: Medical care industry}

This plan aims to develop a medical service system, long-term care system, health care industry, smart medical services in Taiwan, internationalized medical services, national health security, and sound biotech-medical industry in order to build a brand of medical services for Taiwan and facilitate the development of related industries.

(6). P6: Cultural and creative industry

The government adopts the measures of diverse capital investments, industrial counseling, talent development and matching, market circulation and expansion, industrial clustering effects, and interdisciplinary integration and value-added applications to facilitate the six major fields of this industry, namely, television, film, popular music, digital content, design, and craft.

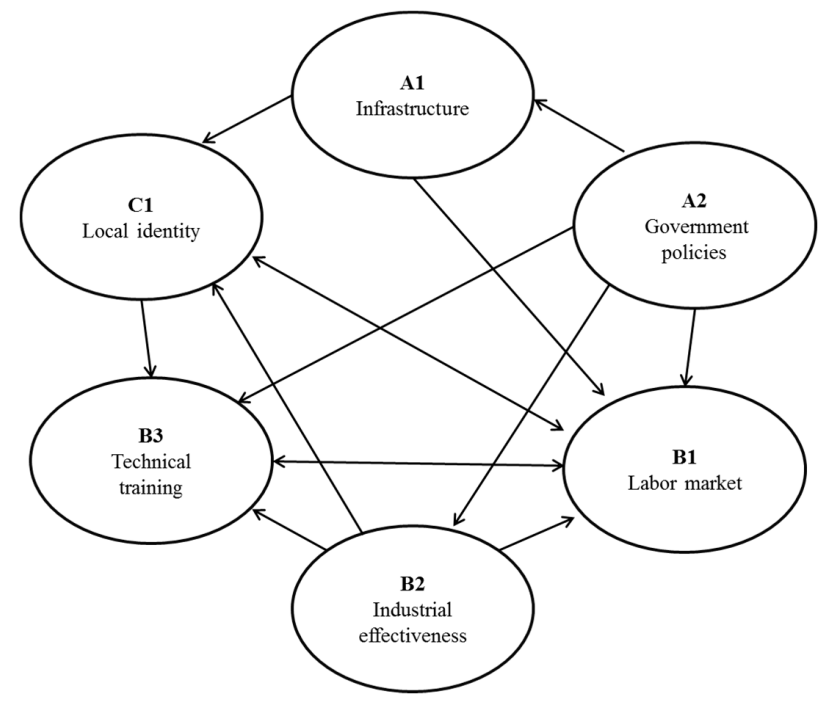

Figure 1. Internal interdependence among the six assessment factors. 


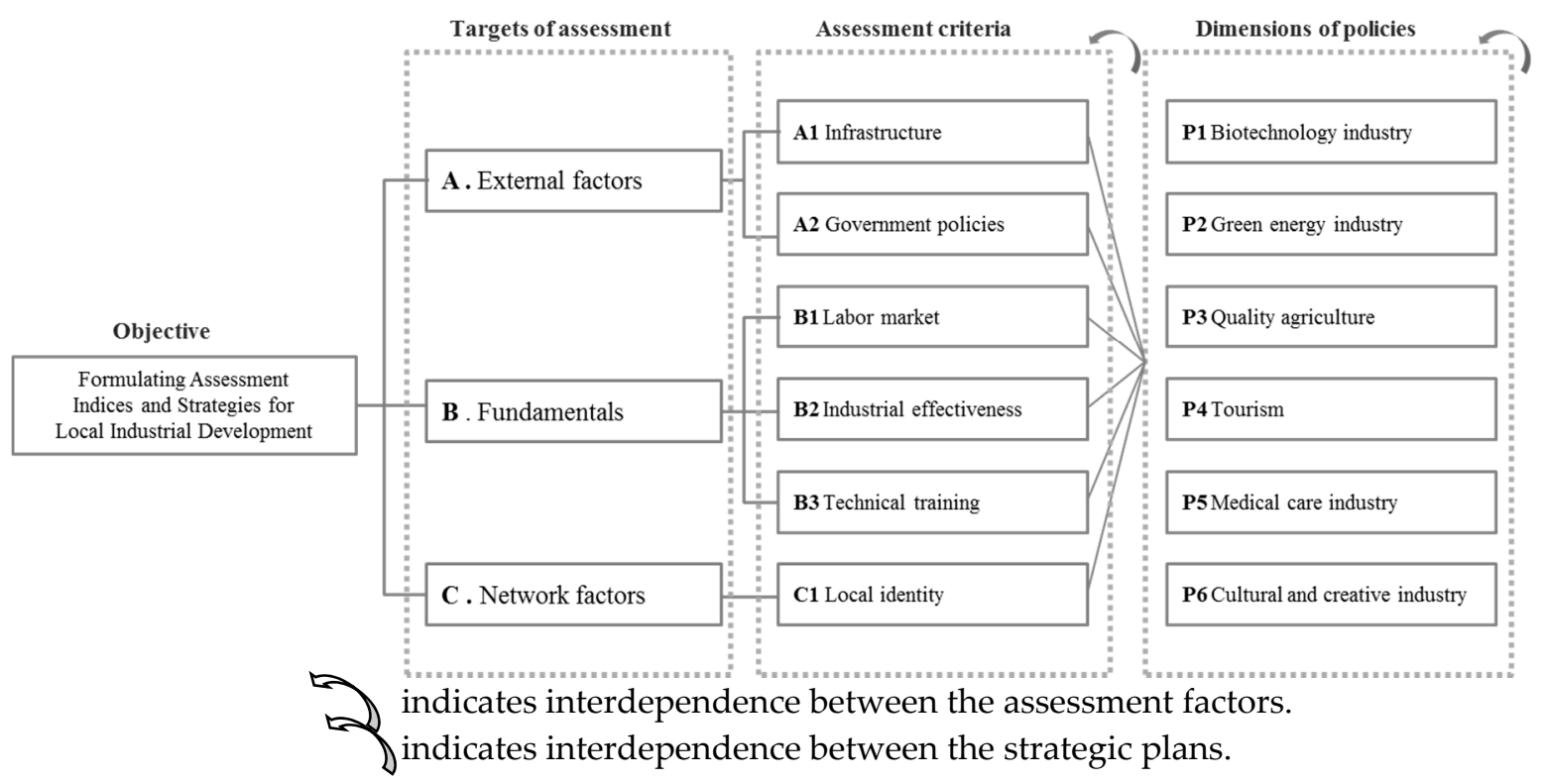

Figure 2. Framework of the assessment indices and strategies for local industrial development.

\subsection{Determining Priorities for Local Industrial Strategies}

This study employed the ANP proposed by Saaty (1996) [31] to perform expert assessment and selection through a questionnaire and obtained seven local industry-related experts' opinions on local industrial development strategies. The results showed that different local industrial development indices can be ranked according to their relative importance $\left(W_{1}\right)$ in a descending order as follows: B1 (30.52\%), A1 (24.26\%), B3 (15.86\%), A2 (15.61\%), B2 (7.84\%), and C1 (5.91\%), indicating that industrial effectiveness, infrastructure, and innovative R\&D are crucial factors and indices that affect local industrial development. When the interactions between different local industrial development indices are considered, the indices can be ranked according to their relative importance $\left(W_{C}\right)$ in a descending order as follows: A2 (33.54\%), A1 (23.23\%), B3 (14.69\%), B1 (10.59\%), C1 (9.34\%), and B2 $(8.60 \%)$, indicating that government, infrastructure, and innovative R\&D are factors and indices affecting local industrial development that exhibit higher importance. The percentages of all the indices' weights are compiled in Table 7 and illustrated in Figure 3. Therefore, infrastructure, innovative $R \& D$, industrial effectiveness, and government policies are crucial development indices, and these indices with higher weights will exert stronger influence on the selection of local industrial development strategies.

Table 7. Local industrial development indices ranked according to their importance.

\begin{tabular}{|c|c|c|c|c|c|c|}
\hline \multirow{2}{*}{$\begin{array}{l}\text { Rankings of } \\
\text { Importance }\end{array}$} & \multicolumn{3}{|c|}{ Weights of Local Industry Indices $\left(W_{1}\right)$} & \multicolumn{3}{|c|}{ Weights of Local Industry Indices $\left(W_{C}\right)$} \\
\hline & Item & Weight & $\%$ & Item & Weight & $\%$ \\
\hline 1 & B1 Industrial effectiveness & 0.30521 & $30.52 \%$ & A2 Government policies & 0.335405 & $33.54 \%$ \\
\hline 2 & A1 Infrastructure & 0.24257 & $24.26 \%$ & A1 Infrastructure & 0.232297 & $23.23 \%$ \\
\hline 3 & B3 Innovative R\&D & 0.15863 & $15.86 \%$ & B3 Innovative R\&D & 0.146929 & $14.69 \%$ \\
\hline 4 & A2 Government policies & 0.15609 & $15.61 \%$ & B1 Industrial effectiveness & 0.105945 & $10.59 \%$ \\
\hline 5 & B2 Technical training & 0.07838 & $7.84 \%$ & C1 Regional networks & 0.093442 & $9.34 \%$ \\
\hline 6 & C1 Regional networks & 0.05912 & $5.91 \%$ & B2 Technical training & 0.085983 & $8.60 \%$ \\
\hline
\end{tabular}






Figure 3. Local industrial development indices ranked according to their importance.

The analytic hierarchy process (AHP) and ANP were adopted to compare the relative importance $\left(\mathrm{W}^{A H P}\right)$ of the industrial action plans when the interactions between local industrial development indices were not considered. The priorities of the development strategies are presented in a descending order as follows: P1 (19.35\%), P2 (18.81\%), P5 (17.69\%), P4 (15.77\%), P6 (14.63\%), and P3 (13.75\%). When the interactions between the local industrial development indices were considered, the industrial action plans can be ranked according to their relative importance $\left(\mathrm{W}^{A N P}\right)$ in a descending order as follows: P1 (21.63\%), P5 (18.99\%), P2 (18.25\%), P6 (16.11\%), P4 (15.05\%), and P3 (9.97\%). The results derived using the AHP and ANP differed slightly. However, after assessment and selection, all the experts have given priority to developing the industries of biotechnology, green energy, and medical care among all the local industrial development strategies. The rankings of all the local industrial development strategies are compiled in Table 8 and illustrated in Figure 4.

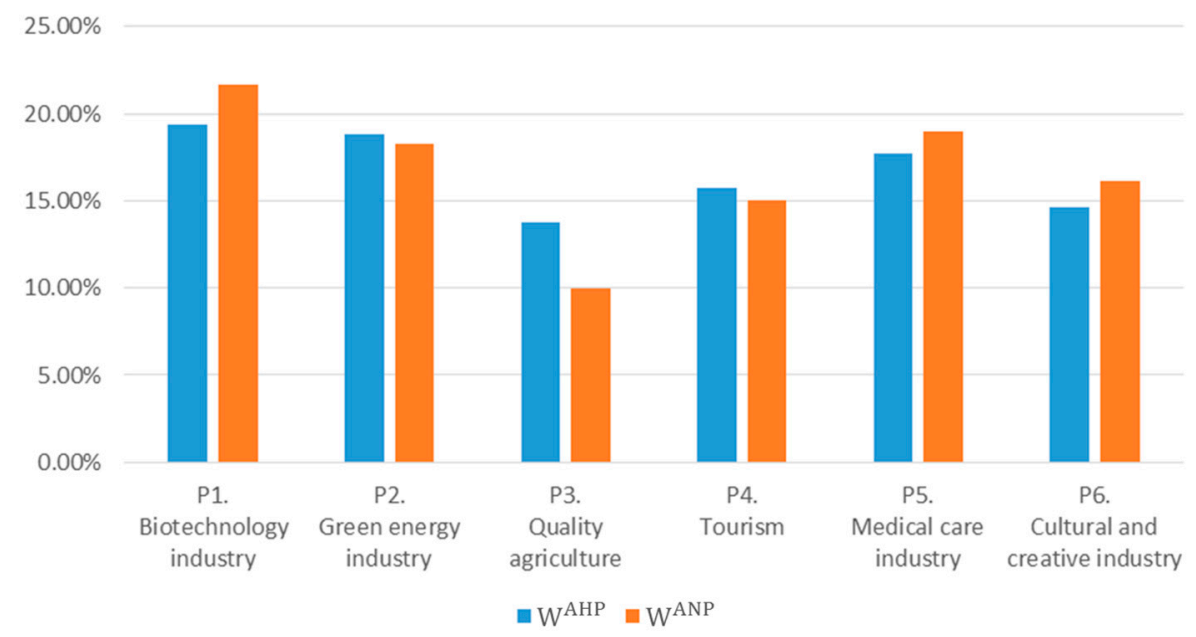

Figure 4. Rankings of importance of the local industrial development strategies assessed using the local industrial development indices. 
Table 8. Rankings of importance of the local industrial development strategies assessed using the local industrial development indices.

\begin{tabular}{ccccccc}
\hline \multirow{2}{*}{$\begin{array}{c}\text { Rankings of } \\
\text { Importance }\end{array}$} & \multicolumn{2}{c}{$\begin{array}{c}\text { Weights of Local Industrial Development } \\
\text { Strategies }\left(\mathbf{W}^{A H P}\right)\end{array}$} & \multicolumn{2}{c}{$\begin{array}{c}\text { Weights of Local Industrial Development } \\
\text { Strategies }\left(\mathbf{W}^{A N P}\right)\end{array}$} \\
\cline { 2 - 7 } & Item & Weight & $\%$ & Item & Weight & $\%$ \\
\hline 1 & P1 Biotechnology industry & 0.19347 & $19.35 \%$ & P1 Biotechnology industry & 0.21629 & $21.63 \%$ \\
2 & P2 Green energy industry & 0.18813 & $18.81 \%$ & P5 Medical care industry & 0.18994 & $18.99 \%$ \\
3 & P5 Medical care industry & 0.17691 & $17.69 \%$ & P2 Green energy industry & 0.18246 & $18.25 \%$ \\
4 & P4 Tourism & 0.15771 & $15.77 \%$ & P6 Cultural and creative industry & 0.16105 & $16.11 \%$ \\
5 & P6 Cultural and creative industry & 0.14628 & $14.63 \%$ & P4 Tourism & 0.15053 & $15.05 \%$ \\
6 & P3 Quality agriculture & 0.13751 & $13.75 \%$ & P3 Quality agriculture & 0.09973 & $9.97 \%$ \\
\hline
\end{tabular}

\subsection{Discussion on the Major Development Policies for Taoyuan City}

The project of Taoyuan Aerotropolis is one of the national major development plans proposed in 2008. Taoyuan City is situated in a location with international logistic advantages and has an airport and a convenient transportation network system. Therefore, the government intends to use these advantages to develop Taoyuan City as Taiwan's gate to the international community, improve the overall development of Taoyuan, and facilitate industrial transformation and internationalization in Taiwan. The project of Taoyuan Aerotropolis involves four major goals: (a) using core areas to facilitate peripheral development and establishing a complete structure consisting of transportation, industries, and urban cores; (b) establishing a new-generation metropolis and lifestyle while developing a green, sustainable, and smart city; (c) facilitating high-tech industrial transformation of the next phase for Taiwan; and (d) facilitating industrial internationalization in Taiwan, improving competitiveness, and finding new prospects for high-tech industries (Taoyuan City, 2015 [8]). These goals indicate that Taoyuan currently aims to develop logistics and high-tech industries. In 2016, the new government proposed the plan of establishing an Asian Silicon Valley, attempting to build a park for exchanges related to start-ups, $R \& D$, and talent development. Currently, the government plans to base the park primarily in Taoyuan City. Although the plan is still under development, the government's expectation of using Taoyuan as a base for facilitating innovative and high-tech industries can be identified. This result also corresponds with the analytical results of this study. Therefore, given that the government policies are compatible with expert opinions, future studies can further analyze the current conditions of Taoyuan City in detail, and formulate specific industrial development goals and strategies.

\section{Conclusions}

The factors and influences of globalization, changes in industrial structures, and information technology development have forced local industries to upgrade or transform in order to enhance their competitiveness. Local industries are the major source of urban competitiveness and closely related to the overall national economic performance. Therefore, countries worldwide have spared no efforts to facilitate and develop local industries. Local industrial development is affected by multiple factors. Therefore, this study first employed the FDM to establish the indices for assessing local industrial development, referred to the action plans for the six key industries formulated by the Executive Yuan of Taiwan, used Taoyuan City as the target for empirical research, and subsequently integrated the AHP and ANP to derive the expert opinions and the corresponding priority of promoting local industrial development strategies for Taoyuan City. The results of this study are described as follows:

\subsection{Establishing the Development Indices for Local Industries}

This study generalized and compiled domestic and international indices related to urban competitiveness, formulated assessment indices for local industrial development, and employed the FDM-based expert questionnaire to determine the values of expert consensus for the six factors, which are presented in a descending order as follows: industrial effectiveness (7.86), government policies (7.76), innovative R\&D (7.39), infrastructure (6.85), technical training (6.44), and regional 
networks (6.35). The expert consensus values of all the six factors satisfied the threshold of 6.35, indicating that the six assessment indices obtained consistent expert consensus and were crucial factors for local industrial development. Subsequently, this study compared and analyzed the relative importance $\left(\mathrm{W}_{1}\right)$ of the six indices for local industrial development, as well as the relative importance $\left(\mathrm{W}_{\mathrm{C}}\right)$ of the indices whose interdependence was considered. The results indicated that infrastructure, innovative $R \& D$, government policies, and industrial effectiveness are critical indices that exert strong influence on local industrial development.

\subsection{Formulating Action Plans for Local Industries}

After referring to the action plans for six key industries formulated by the Executive Yuan of Taiwan in 2009, this study employed an expert questionnaire, performed the traditional AHP and the ANP, and used matrixes to calculate and determine the relative importance of local industrial development indices to the action plans for the six key industries, as well as such relative importance when the interdependence between the indices was considered. Subsequently, the calculated weights were used to assess, select, and recommend which action plans that should be prioritized. When the local industrial development indices were not internally interdependent, the action plans selected and assessed using the AHP can be ranked according to their weights as follows: P1 (19.35\%), P2 (18.81\%), P5 (17.69\%), P4 (15.77\%), P6 (14.63\%), and P3 (13.75\%). When the indices were internally interdependent, the action plans can be ranked using the same method as follows: P1 $(21.63 \%)$, P5 (18.99\%), P2 (18.25\%), P6 (16.11\%), P4 (15.05\%), and P3 (9.97\%).

The rankings of priority of industrial action plans derived using the traditional AHP and the ANP differed slightly. However, the industries of biotechnology, green energy, and medical care represented the top three plans in both cases, accounting for $19.35 \%, 18.81 \%$, and $17.76 \%$, respectively. In other words, the experts considered the biotechnology industry to be the most suitable industry for Taoyuan City to develop, followed by the green energy and medical care industries. According to the plan of the biotechnology industry in the industrial policies compiled in this study, the central and local governments can start to promote the industry by improving the industrializing and R\&D capacity of research institutions specialized in health (e.g., medicine, pharmaceutical biotechnology, and medical technology), industry (e.g., chemistry, energy, materials, and foods), and agriculture (e.g., agriculture, husbandry, fishing, and forestry). In addition, the governments can consider establishing biotechnology integration incubation centers and venture capital funds to facilitate cooperation between government and private capital and develop modes of private, domestic, and foreign investments. Furthermore, the government should establish a food drug administration to construct a medical regulatory environment compatible with the international community to improve related laws and regulations. In the plan of the green energy industry, the government should enhance the advantages of renewable energy (e.g., solar photovoltaic and wind power) and energy conservation (e.g., LED photoelectric lighting and energy information and communication) in Taiwan. The government should adopt strategies such as technology advancement, critical investments, environmental shaping, domestic demand expansion, and export promotion to strengthen the competitive advantages of solar cell technology, guide businesses to create an offshore wind power market, and improve the advantages in the production and system of LED lighting components. By doing so, the industry will enhance its industrial capacity through the domestic market, concentrate on advanced metering infrastructure systems and energy management programs, and create an overseas niche market. In the plan of the medical care industry, the government should aim to develop a medical service system, long-term care system, health care industry, smart medical services in Taiwan, internationalized medical services, national health security, and sound biotech-medical industry in order to build a brand of medical services for Taiwan and facilitate the development of related industries. The results of this study corresponded with the industrial development strategies currently actively promoted by governments worldwide. The results of this study corresponded with the direction of policies developed by the current government and the characteristics of regional industrial development indicated by the experts. 
However, whether the government can succeed in facilitating local industrial growth still depends on the actual implementation of the policies and various action plans. The indices identified in this study can be continuously used for policy assessment and correction in the future. In addition, the indices and plans in this study can be used to assess other regions to further identify the possibility and feasibility of local industrial development.

\subsection{Establishing and Applying the Action Plans for Local Industrial Development}

This study employed the FDM to select assessment indices, performed the convention AHP and the ANP to develop critical indices affecting local industrial development, and calculated the order of priorities among the industrial development plans to provide countries worldwide with an objective and reliable reference and assessment method for making policies to facilitate local industrial development. This research argues that government policies can influence the local industrial development. For example, the six key emerging industries in 2008 that proposed by the KMT government tends to focus on the culture and tourism industries while the current DPP government emphasizes on the high-tech innovation and machinery industries. That is, the project Asian Silicon Valley can mostly illustrate the ambition of the government and look forward to building Taoyuan City as the heart of the innovation and high-tech industries foundation. Moreover, this research concludes that Taoyuan City should focus on the biotechnology, green energy and the medical care industries that turned the traditional economic growth into "green growth." There is a new trend towards "green growth" as a way to decouple economic activity from consumption and environmental impacts is fundamental to future human well-being. The results also matched the government industrial policies; consequently, it could support both local and central governments to conduct further analysis of the industrial development policies and create the incentives for the investments in the future. While keeping abreast with various countries' promotion of urban industrial transformation, upgrade, and the development of creative industries, the government should propose a policy that is favorable to developing the overall urban industrial development and enhancing urban competitiveness. This study adopted FDM, AHP and ANP as the research methodology to provide crucial indices and the priorities among the different industrial policies to decision-makers. The research procedure and results of this study can serve as a reference for countries worldwide to facilitate local industrial development related studies in the future.

Acknowledgments: This study is a part of the research outcome of a project named "An investigation into the policy of city development based on the cultural creative industry" (MOST105-2410-H-845-011-MY3-), which was funded by the Ministry of Science and Technology in Taiwan. We thank the Ministry for funding this project.

Author Contributions: The individual contribution and responsibilities of the authors were as follows: Yin-Hao Chiu: Research idea and method design, grant holder of research financing, article writing, related data collection and analysis, supervision of the research direction. Yung-Cheng Pan: research idea, literature review, research data analysis, article writing.

Conflicts of Interest: The authors declare no conflict of interest.

\section{References}

1. Liau, S.J.; Chou, T.L. The Primary Study of Local Development Institution Form in Taiwan: The Discussion of Some Northern Coastal Areas. J. Archit. Plan. 2000, 1, 13-34.

2. Fan, S.M.; Chou, T.L. Local Development Strategies in Taiwan: Governance and Networking. J. City Plan. 2008, 35, 99-122.

3. Barberia, L.G.; Biderman, C. Local economic development: Theory, evidence, and implications for policy in Brazil. Geoforum 2010, 41, 951-962. [CrossRef]

4. Leidecker, J.K.; Bruno, A.V. Identifying and using critical success factors. Long Range Plan. 1984, 17, $23-32$. [CrossRef]

5. Ching, C.H.; Chou, T.L. Differentiations in Taiwan's Regional Industrial Clusters: The Impacts of China Effects. J. Geogr. Sci. 2007, 49, 55-79. 
6. Small and Medium Enterprise Administration. White Paper on Small and Medium Enterprises; Small and Medium Enterprise Administration: Taipei, Taiwan, 2005.

7. Council for Economic Planning and Development. Challenge 2008: National Development Plan (2002-2007); Council for Economic Planning and Development, Executive Yuan: Taipei, Taiwan, 2005.

8. Taoyuan City Government. Taoyuan Aerotropolis Project. Available online: http://www.tycg.gov.tw/ aerotropolis/ (accessed on 15 August 2015).

9. Porter, P. Clusters and the new economics of competitiveness. Harv. Bus. Rev. 1998, 76, 77-90. [PubMed]

10. Cooke, P.; Uranga, M.G.; Etxebarria, G. Regional systems of innovation: An evolutionary perspective. Environ. Plan. A 1998, 30, 1563-1584. [CrossRef]

11. Cooke, P. Regional innovation system, clusters, and the knowledge economy. Ind. Corp. Chang. 2001, 10, 945-974. [CrossRef]

12. Lin, K.F.; Hu, T.S.; Hsieh, H.N.; Chia, P.C. Industrial Cluster Formation and Evolution-The Case of Hsinchu Area. J. Archit. Plan. 2012, 13, 45-74.

13. Yen, Y.C.; Kung, S.F. Identification of Horizontal Spatial Clustering and Its Spatial Structure: The Case of Manufacturing Industries in Taiwan. J. City Plan. 2014, 41, 117-148.

14. Yung, Y.C.; Kung, S.G.; Wang, F.S. Industrial Development and Spatial Distribution of Regional Clusters in Southern Taiwan. J. Public Aff. Rev. 2009, 10, 109-145.

15. Yu, C.L.; Lu, D.B.; Luo, M.S. The Study of Local Charm Industries Design Process: A Case Study of Baihe Lotus Industry. Baihe Lotus Industry. J. Archit. 2010, 72, 129-146.

16. Chen, L.C. An Analysis on the Local Characteristic Industry in Taiwan. J. Chin. Trend Forw. 2007, 3, 81-98.

17. Liau, S.J.; Chou, T.L. The Globalization and Taiwan's Local Redevelopment Strategies. J. City Plan. 2000, 27, 191-209.

18. Liau, S.J. Globalization, State Regulation and Local Development. J. City Plan. 2005, 32, $25-56$.

19. National Development Council. Six Emerging Industries. Available online: http://www.ndc.gov.tw/News. aspx?n=E641F7FF2AE058A1\&sms=8B7FD77816422CEF (accessed on 17 August 2015).

20. National Development Council. Five Innovative Industries. Available online: http://www.ey.gov.tw/ policy9/cp.aspx?n=1EB1D1DD8C83B9C0 (accessed on 17 August 2015).

21. Buckley, P.J.; Pass, C.L.; Prescott, K. Measures of international competitiveness: A critical survey. J. Mark. Manag. 1988, 4, 175-200. [CrossRef]

22. Lee, H.T.; Yen, S.L. The Development of Miao-li Local-Characteristics Industry and Its Competitiveness Analysis. Yu Da Acad. J. 2006, 11, 49-74.

23. Huang, C.J. Industry Planning of Organic Agriculture of Taiwan. Chin. J. Agribus. Manag. 1998, 4, $102-126$.

24. Coelli, T.J.; Prasada Rao, D.S.; O’Donnell, C.J.; Battese, G.E. Introduction Efficiency Productivity Analysis; Kluwer Academic Publishers: Dordrecht, The Netherlands, 1998.

25. Yao, S.S.; Chiang, Y.S.; Wang, S.E. Total Factor Productivity Change and Effects of Production Environment in Taiwan. J. Plan. 2001, 28, 1-23.

26. Dunning, J.H. The eclectic paradigm of international production: A restatement and some possible extensions. J. Int. Bus. Stud. 1988, 19, 1-31. [CrossRef]

27. Taiwan Institute of Economic Research. Investigation of Characteristic Industry in Taipei Wanhua, Datong; Business Administration Commissioned Taipei: Taipei, Taiwan, 2001.

28. Coelli, T.J.; Rao, D.S.P.; O’Donnell, C.J.; Battese, G.E. An Introduction to Efficiency and Production Analysis; Springer: New York, NY, USA, 2005.

29. Jeng, T.-B. Fuzzy Assessment Model for Maturity of Software Organization in Improving its Staff's Capability. Master's Thesis, Graduate Institute of Information Management, National Taiwan University of Science and Technology, Taipei, Taiwan, 2001.

30. Wu, J.-Y.; Huang, Y.-S. The Establishment of Vulnerability Evaluation Indices: The Case of Shueili Township, Nantou, Taiwan. J. City Plan. 2011, 38, 195-218.

31. Saaty, T.L. The Analytic Network Process; RWS Publications: Pittsburgh, PA, USA, 1996.

(C) 2017 by the authors. Licensee MDPI, Basel, Switzerland. This article is an open access article distributed under the terms and conditions of the Creative Commons Attribution (CC BY) license (http:/ / creativecommons.org/licenses/by/4.0/). 